\title{
Valorisation of food waste to biofuel: current trends and technological challenges
}

\author{
Sanjib Kumar Karmee and Carol Sze Ki Lin ${ }^{*}$
}

\begin{abstract}
Demand for biofuels is rapidly growing worldwide as petroleum based fuels are finite reserves. In this context, biodiesel and bioethanol are popular biofuels that are commercially available in various countries. Biofuels can be prepared from edible biomass. However, this is already generating food versus fuel debate among the members of civil societies. Therefore, there are needs to synthesize biofuels from nonedible waste materials. Food wastes can be utilized as resources for the production of biodiesel and bioethanol since they contain significant amount of lipids and carbohydrates. In future, industrial production of biodiesel and bioethanol from food waste can contribute to resolve the waste disposal, energy scarcity and energy security problems.
\end{abstract}

Keywords: Food waste, Biofuel, Biodiesel, Bioethanol, Sustainable chemistry

\section{Introduction}

Food waste is creating serious environmental and social problems in Hong Kong and across the world. According to a recent report released by the Hong Kong Environment Bureau, among the 9,000 tonnes of municipal solid waste that is thrown away everyday at landfills, $40 \%$ of which is composed of "putrescibles" [1]. These putrescibles are organic wastes that are known to create odour upon decomposition. Approximately, $90 \%$ of putrescibles are food wastes. Food waste can be raw, cooked, edible and inedible parts generated during production, storage distribution, and consumption of food stuffs. In 2011, Hong Kongers threw away approximately 3,600 tonnes of food waste everyday $[1,2]$. Two third of the food waste was obtained from household; whereas, one third of food waste came from commercial and industrial sources. Hong Kong is not the only country generating large quantities of food waste. For instance, other developed cities like Taipei and Seoul are producing 182,000 tonnes/per year and 767,000 tonnes/per year of food wastes respectively $[1,2]$.

The food wastes produced in Hong Kong includes rotten fruits, vegetables, fish, poultry organs, fruits and vegetable peelings, meat, fish, shellfish shells, bones, food fats, sauces, condiments, soup pulp, Chinease medicinal pulp, egg shells, cheeses, ice cream, yogurts, tea leaves, teabags,

\footnotetext{
*Correspondence: carollin@cityu.edu.hk

School of Energy and Environment, City University of Hong Kong, Tat Chee Avenue, Kowloon, Hong Kong
}

coffee grounds, breads, cakes, biscuits, desserts, jam, different cereals, leftover of cooked food, BBQ raw or cooked leftovers, and pet food [1]. The Hong Kong Government plans to cut down the food waste that goes to landfill to approximately $40 \%$ by 2022 . Landfills are the most common place for garbage deposition. Landfills spread offensive smell and are known to cause hazardous effects on people, animals, and the environment. Landfills are unsustainable as they produce methane which is a common green house gas. Furthermore, landfills also generate large amount of harmful leachate when rainwater falls on the garbage. This leachate can contaminate water and soil. Nevertheless, anaerobic digestion of food wastes that occurs naturally in the absence of oxygen employing bacteria can be used to produce biogas. Biogas is used as an energy source. Alternatively, food wastes can be valorized for the production of energy by using different common techniques such as composting, recycling and incineration. Although, these processes are capable of converting food waste into fuels and value-added products development of greener and advanced technologies are required [3].

Biofuel production is rapidly growing as the world encounters pollution problems due to burning of petroleum and coal based fuels. In addition, petroleum fuels are finite reserves and most of the petroleum reserves are geographically located in politically unstable countries. This reinforces the fact that alternative fuels are important from both environmental and energy security point of view. 
Along this line, many countries are formulating energy policies for the production of renewable energy.

At present, biofuels such as biodiesel and bioethanol are largely produced from edible food materials [4]. Various edible plant oils from soybean, rapeseed and canola oils are used for the preparation of biodiesel. Whereas, ethanol can be produced from a variety of feedstocks such as sugar cane, bagasse, sugar beet, grain, switchgrass, barley, potatoes, molasses, corn, stover, wheat and many other sources rich in carbohydrate $[4,5]$. Chemical biodiesel production process is called transesterification $[4,5]$. During transesterification, the tri-,di-and monoglycerides react with methanol in the presence of a catalyst to produce biodiesel. On the other hand, the production of bioethanol process involves pretreatment, enzymatic hydrolysis, fermentation and distillation steps. Preparation of biofuels from edible food materials is attributed for the reason of food scarcity and a food vs fuel debate is already raging [6]. Alternatively, nonedible feedstocks can be used for the production of biofuels. Jatropha, Pongamia and other nonedible plant oils are already used for the preparation of biodiesel [5]. Along this line, nonedible lignocellulosic biomass is also employed for the production of bioethanol [7].

Food waste is a well-known nonedible source of lipids, carbohydrates, amino acids and phosphates [8,9]. Reserach in our laboratory reveals that bakery and mixed food wastes contain significant amount of lipids and carbohydrates $[8,9]$. Depending on the source of food waste the average lipid content was around $30 \%$ and the average carbohydrate content was around 50\% [8,9]. Different types of food wastes can be hydrolysed enzymatically to produce food hydrolysate and lipids [8,9]. The food hydrolysate was rich in carbohydrate and can be used for the production of bioethanol; whereas, the obtained lipid can be converted to biodiesel (Figure 1).

Along this line, noodle is a common starch based food material. In South Korea around 3 billion packages of instant noodle were consumed in 2011 and more than 2,100 tons of instant noodle residues were disposed as waste. Kim et al. have used instant noodle waste for the production of biofuels [10,11]. Kim et al. recovered the oil from noodle waste by extraction using nonpolar hexane as a solvent. From $100 \mathrm{~g}$ of noodle waste $83 \mathrm{~g}$ of purified starch and $5 \mathrm{~g}$ of oil was obtained. The obtained oil free starch residue was used for simultaneous saccharification and fermentation process for the production of bioethanol $[10,11]$. The hexane extract was evaporated and the obtained oil was reacted with methanol in the presence of acid and alkali catalysts for the preparation of biodiesel. One major limitation of this process is that the excess use of hexane during the extraction of oil from food waste $[10,11]$. The Centers for Disease Control classifies n-hexane as a neurotoxin. It is also listed as a "hazardous air pollutant" by the Environmental Protection Agency as it helps in the formation of ozone at the ground level which is primarily responsible for smog. Nevertheless, these experiments demonstrate the potential utilization of waste noodle waste as a resource for biofuel production.

Research on the use of food wastes for the production of biofuel is becoming attractive in different countries. Sulaiman et al. have conceptualized a halal biorefinery for the production of fuels and value added products in Malaysia [12]. Yao et al. from the Chinese Academy of Sciences investigated the application of food waste to generate hydrolysates for the production of bioethanol [13]. In this context, potato peel is a well-known waste generated by the potato industries in Europe [14]. As

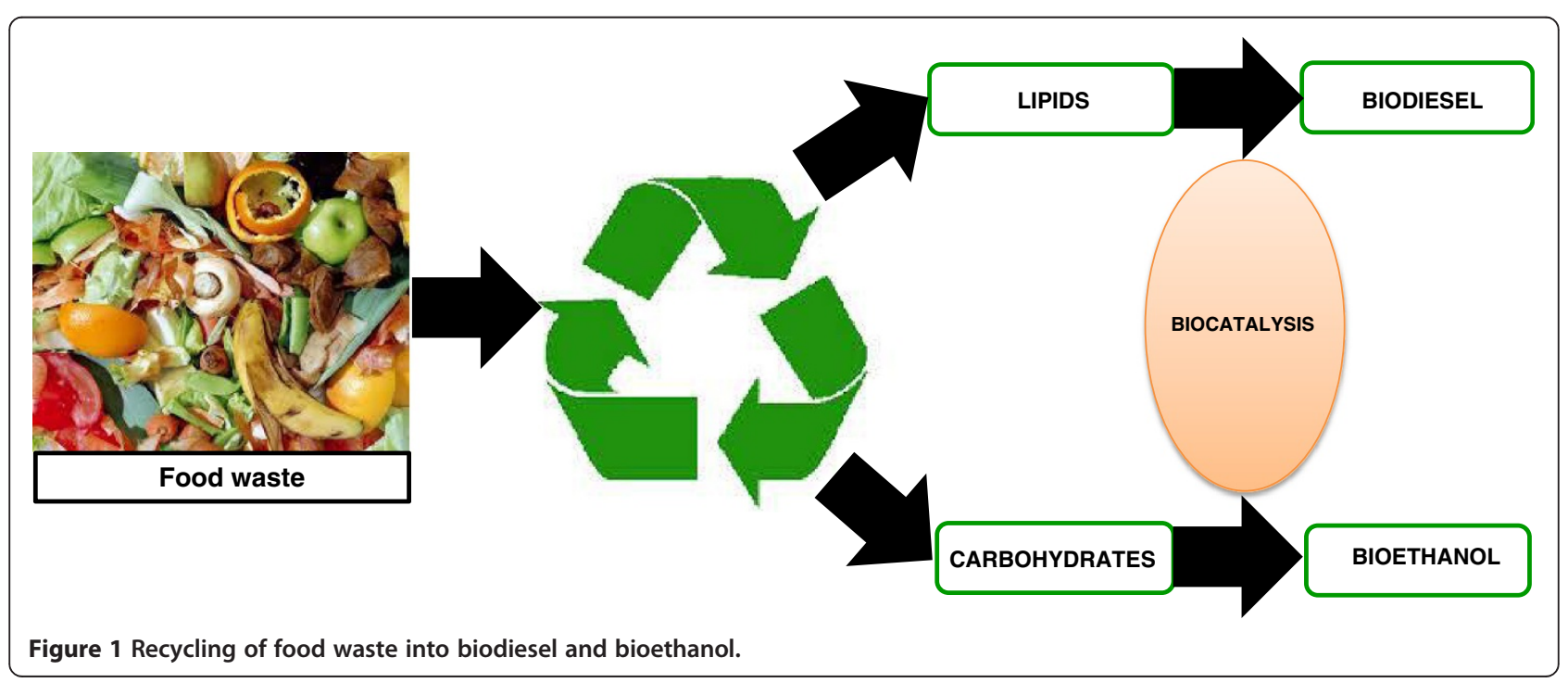


reported by Christakopoulos.et al. this "no value" potato peel waste was converted to bioethanol using environmentally benign biocatalytic methods [13]. Researchers have also used household food waste for the production of bioethanol. During this process liquefaction and saccharification methods were employed to increase both ethanol production and productivity of the process [15]. Subsequently, fermentation of the remaining solids obtained from this process was performed to increase the overall yield of ethanol [15].

It is clear from the above discussion that environmental pollution and upcoming shortage of fossil fuels have turned the attention of researchers largely on the utilization of renewable feedstocks. Additionally, scientists and policy makers are devoting much efforts to use nonedible and zero cost food wastes for fuel and energy production to reduce the direct competition between fuel and food. It is known that food wastes are generated in large quantities and their handling is a challenge. As discussed earlier, these food wastes are potential resources as they contain substantial amount of carbohydrates and lipids. Thus, zero value food waste can be used as a resource for the production of low-cost biofuels. Research by various groups is currently underway for the production of biodiesel and bioethanol from food waste [16-22]. So far, the "proof of concept" for the synthesis and characterization of biofuels from different food wastes has been established [16-22].

Currently, technologies are available for the production of biodiesel and bioethanol in industrial scale. In this regard, a pilot scale production of ethanol from food waste using Saccharomyces cerevisiae H058 is already reported [22]. Nevertheless, low cost, greener and advanced technologies are needed for the production of fuels from food wastes [3,23]. The industrial production of biofuel from food waste is largely depended on i) availability of food waste, ii) efficiency of hydrolyis process, iii) the amount of lipid and carbohydrate obtained from food waste, and iv) efficiency of fermentation and transesterification methods. In Hong Kong, Taiwan, Korea, US and in many other European countries plenty of food wastes are available. Thus, the future work should be primarily focused on large scale pretreatment and hydrolysis of food waste for production of lipid and sugar enriched hydrolysate. Several microorganisms and enzymes are known to hydrolyze food waste to carbohydrate, lipid, amino acids and phosphates. The catalytic efficiencies of the existing biocatalysts can be tested for the large scale hydrolysis of food wastes. Afterwards, the commercially available technologies can be employed for the production of biodiesel and bioethanol.

To make biofuels economically viable, the business and scientific communities and policy makers should come together to start a joint venture into the business of converting food waste into fuels. With proper financial and policy based supports from government, food waste biorefineries can be realized. In this context, it is particularly important to overcome the existing technological challenges of conventional food waste valorization methods. Simultaneously, it is crucial to develop environmental friendly and cost effective recycling methods that can convert food wastes into biofuels and chemicals [24-26]. Recently, combi-protein coated microcrystals of lipases are used for the production of biodiesel from oil of spent coffee grounds [27]. In this regard, both chemo- and biocatalytic methods can be explored for the preparation of biofuels from food waste [27-31].

\section{Conclusions}

Since food waste is considered zero cost material it is possible to develop cost-effective commercial methods for the production of biofuel using lipid and carbohydrate generated from food waste. Research on the conversion of food waste into biofuel will provide an innovative food valorisation strategy; which could contribute substantially to bio-based economy. The future goal of this research should focus on investigation of the feasibility of utilizing food waste into biofuel through simple and clean methods. Utilisation of lipid and carbohydrates obtained from food waste for biofuel production is an excellent example to demonstrate the enormous potential of waste valorisation for building a sustainable society.

\section{Competing interests}

The authors declare that they have no competing interests.

\section{Authors' contributions}

SKK contributed to the writing of the manuscript. CSKL assisted in the revision of manuscript. The final version was read and approved by both authors.

\section{Authors' information}

SKK is currently a postdoctoral fellow and CSKL is an Assistant Professor in the School of Energy and Environment at the City University of Hong Kong.

\section{Acknowledgements}

SKK is grateful to the School of Energy and Environment, City University of Hong Kong for a postdoctoral fellowship under the Graduate Teaching Assistant (GTA) scheme.

Received: 29 July 2014 Accepted: 22 October 2014

Published online: 19 November 2014

\section{References}

1. A food waste \& yard waste plan for Hong Kong. 2014-2022. http://www. enb.gov.hk/en/files/FoodWastePolicyEng.pdf, accessed on 30.06.2014.

2. Monitoring of solid waste in Hong Kong. https://www.wastereduction.gov. hk/en/assistancewizard/waste_red_sat.htm, accessed on 30.06.2014.

3. Luque $\mathrm{R}$, Clark JH: Valorisation of food residues: waste to wealth using green chemical technologies. Sustainable Chem Process 2013, 1:10.

4. Pimentel D, Patzek TW: Ethanol production using corn, switchgrass, and wood;biodiesel production using soybean and sunflower. Nat Resour Res 2005, 14:65-76.

5. Karmee SK, Chadha A: Preparation of biodiesel from crude oil of Pongamia pinnata. Bioresour Technol 2005, 96:1425-1429.

6. Mathews JA: Is growing biofuel crops a crime against humanity? Biofuels Bioprod Bioref 2008, 2(2):97-99.

7. Sun $Y$, Cheng J: Hydrolysis of lignocellulosic materials for ethanol production: a review. Bioresour Technol 2002, 83:1-11. 
8. Pleissner D, Lam WC, Sun Z, Lin CSK: Food waste as nutrient source in heterotrophic microalgae cultivation. Bioresour Technol 2013, 137:139-146.

9. Pleissner D, Kwan TH, Lin CSK: Fungal hydrolysis in submerged fermentation for food waste treatment and fermentation feedstock preparation. Bioresour Technol 2014, 158:48-54.

10. Yang X, Lee SJ, Yoo HY, Choi HS, Park C, Kim SW: Biorefinery of instant noodle waste to biofuels. Bioresour Technol 2014, 159:17-23.

11. Yang X, Lee JH, Yoo HY, Shin HY, Thapa LP, Park C, Kim SW: Production of bioethanol and biodiesel using instant noodle waste. Bioprocess Biosyst Eng 2014, doi:10.1007/s00449-014-1135-3.

12. Sulaiman A, Othman N, Baharuddin AS, Mokhtar MN, Tabatabaei M: Enhancing the halal food industry by utilizing food wastes to produce value-added bioproducts. Procedia Soc Behav Sci 2014, 121:35-43.

13. Yan S, Li J, Chen X, Wu J, Wang P, Ye J, Yao J: Enzymatical hydrolysis of food waste and ethanol production from the hydrolysate. Renew Energ 2011, 36:1259-1265.

14. Arapoglou D, Varzakas T, Vlyssides A, Israilides C: Ethanol production from potato peel waste (PPW). Waste Manage 2010, 30:1898-1902.

15. Matsakas L, Kekos D, Loizidou M, Christakopoulos P: Utilization of household food waste for the production of ethanol at high dry material content. Biotechnol Biofuels 2014, 7:4.

16. Kim JH, Lee JC, Pak D: Feasibility of producing ethanol from food waste. Waste Manage 2011, 31:2121-2125.

17. Kim JK, Oh BR, Shin H-J, Eom C-Y, Kim SW: Statistical optimization of enzymatic saccharification and ethanol fermentation using food waste. Process Biochem 2008, 43:1308-1312.

18. Lin CSK, Pfaltzgraff LA, Herrero-Davila L, Mubofu EB, Abderrahim S, Clark JH, Koutinas AA, Kopsahelis N, Stamatelatou K, Dickson F, Thankappan S, Mohamed Z, Brocklesby R, Luque R: Food waste as a valuable resource for the production of chemicals, materials and fuels. Current situation and global perspective. Energy Environ Sci 2013, 6(2):426-464.

19. Kondamundi N, Mohapatra SK, Misra M: Spent coffee grounds as a versatile source of green energy. J Agric Food Chem 2008, 56:11757-11760.

20. Garcia J: Food wasterecycled as biofuel. http://large.stanford.edu/courses/ 2011/ph240/garcia1/, accessed on 30.06.2014.

21. Akpan UG, Alhakim AA, ljah UJJ: Production of ethanol fuel from organic and food wastes. Leonardo Electron J Pract Technol 2008, 13:1-11.

22. Yan S, Chen X, Wu J, Wang P: Pilot scale production of fuel ethanol from concentrated food waste hydrolysates using Saccharomyces cerevisiae H058. Bioprocess Biosyst Eng 2013, 36:937-946.

23. Arancon RAD, Lin CSK, Chan KM, Kwan TH, Luque R: Advances on wastevalorization: new horizons for a more sustainable society. Energy Sci Eng 2013, 1:53-71

24. Zhang AYZ, Sun Z, Leung CCJ, Han W, Lau KY, Li M, Lin CSK: Valorisation of bakery waste for succinicacid production. Green Chem 2013, 15:690-695.

25. Leung CC, Cheung SY, Zhang YZ, Lam KF, Lin CSK: Utilisation of waste bread for the sustainable production of succinic acid. Biochem Eng J 2012, 65:10-15.

26. Koutinas AA, Pleissner D, Vlysidis A, Kopsahelis N, Lopez Garciac I, Kookosd I, Papanikolaou S, Lin CSK: Valorization of industrial waste and by-product streams via fermentation for the production of chemicals and biopolymers. Chem Soc Rev 2014, 43(8):2587-2627.

27. Banerjee A, Singh V, Solanki K, Mukherjee J, Gupta MN: Combi-protein coated microcrystals of lipases for production of biodiesel from oil from spent coffee grounds. Sustainable Chemical Processes 2013, 1:14.

28. Karmee SK: Biocatalytic synthesis of ascorbyl esters and their biotechnological applications. Appl Microbiol Biotechnol 2009, 81(6):1013-1022

29. Karmee SK: Lipase catalyzed synthesis of ester-based surfactants from biomass derivatives. Biofuels Bioprod Bioref 2008, 2:144-154

30. Kiss AA, Dimian AC, Rothenberg G: Solid acid catalysts for biodiesel production- towards sustainable energy. Adv Synth Catal 2006, 348:75-81.

31. Lin CSK, Koutinas AA, Stamatelatou K, Mubofu EB, Matharu AS, Kopsahelis N, Pfaltzgraff LA, Clark JH, Papanikolaou S, Kwan TH, Luque R: Current and future trends in food waste valorization for the production of chemicals, materials and fuels: a global perspective. Biofuels Bioprod Bioref 2014, 8(5):686-715.

doi:10.1186/s40508-014-0022-1

Cite this article as: Karmee and Lin: Valorisation of food waste to biofuel: current trends and technological challenges. Sustainable Chemical Processes 2014 2:22.

\section{Publish with ChemistryCentral and every scientist can read your work free of charge \\ "Open access provides opportunities to our colleagues in other parts of the globe, by allowing anyone to view the content free of charge." \\ W. Jeffery Hurst, The Hershey Company. \\ - available free of charge to the entire scientific community \\ - peer reviewed and published immediately upon acceptance \\ - cited in PubMed and archived on PubMed Central \\ - yours - you keep the copyright \\ Submit your manuscript here: \\ http://www.chemistrycentral.com/manuscript/<smiles>c1ccccc1</smiles> \\ Chemistry Central}

